\title{
A Comparison of Three DNA Extractive Procedures with Leptospira for Polymerase Chain Reaction Analysis
}

\author{
IF Veloso+, MTP Lopes*, CE Salas**, EC Moreira
}

\author{
Laboratório de Zoonoses, Departamento de Medicina Veterinária Preventiva, Escola de Veterinária, \\ *Departamento de Farmacologia **Departamento Bioquímica e Imunologia, ICB, Universidade Federal de \\ Minas Gerais, Av. Antonio Carlos 6627, 31270-901, Belo Horizonte, MG, Brasil
}

Three DNA extraction methods were evaluated in this study: proteinase K followed by phenol-chloroform; a plant proteinase (E6870) followed by phenol-chloroform; and boiling of leptospires in 0.1 $\mathrm{mM}$ Tris, $\mathrm{pH} 7.0$ for $10 \mathrm{~min}$ at $100^{\circ} \mathrm{C}$, with no phenol treatment. Every strain treated with proteinase $\mathrm{K}$ or E6870 afforded positive polymerase chain reaction (PCR) reaction. On the other hand, from five strains extracted by the boiling method, three did not feature the $849 \mathrm{bp}$ band characteristic in Leptospira. We also evaluated by RAPD-PCR, DNAs from serovars isolated with proteinase K and proteinase 6870 with primers B11/B12. Each of the DNA samples provided PCR profiles in agreement with previous data. Moreover, the results with E6870 showed less background non-specific amplification, suggesting that removal of nucleases was more efficient with E6870. The limit for detection by PCR using Lep13/Lep14 was determined to be $10^{2}$ leptospira, using the silver stain procedure.

Key words: polymerase chain reaction - leptospira - DNA extraction

Leptospirosis is an important disease with worldwide distribution affecting wild and domestic animals as well as humans. In cattle, it causes economy losses with abortions, stillbirths, premature live birth and mastites. The main source of contamination is the shedding of Leptospira sp. through urine. The genus Leptospira belongs to the family Leptospiraceae, order Spirochateales (Johnson \& Faine 1994). Conventional classification of leptospires relies on antigenic similarities with serovar as a basic taxon. So far, more than 200 serovars have been identified and grouped in 23 serogroups of antigenically related serovars. Domestic animals can be infected by any of the pathogenic serovars but each serovar usually remains in a specific maintenance host. Only a small number of serovars are endemic in any particular region or country (Ellis 1986). Hardjo, which is the serovar kept by cattle, has two genotypes, Hardjobovis and Hardjoprajitno, both found in cattle and sheep (Ellis 1994).

Current diagnosis methods for leptospirosis lack sensibility and specificity and are time consuming. Direct microscopic analysis of fresh urine

\footnotetext{
This work was supported by Fapemig and CNPq.

${ }^{+}$Corresponding author. Fax: +55-31-499.2646. E-mail: profisio@brhs.com.br

Received 3 August 1999

Accepted 27 January 2000
}

has limitations for it needs relatively large number of leptospires for visualization. The serological method of choice is the microscopic agglutination test (MAT), but it fails to detect antibodies during chronic infections or in the early phase of the disease. Although culture techniques can be used to detect leptospires in urine, these procedures are slow, laborious and the samples are susceptible to contamination. For the diagnosis of leptospirosis, a rapid and sensitive assay must be able to detect leptospires in blood or urine of infected animals. The polymerase chain reaction (PCR) may fulfill these requirements. In recent years, PCR has been used to detect leptospires and other microorganisms in biological samples like urine (Van Eys et al. 1989, Gerritsen et al. 1991, Mérien et al. 1992, Bal et al. 1994, Brown et al. 1995), serum (Mérien et al. 1992, Gravekamp et al. 1993, Brown et al. 1995), liquor (Mérien et al. 1992, Romero et al.1998), milk (Zanini et al. 1998), and semen (Masri et al. 1997). The success of PCR depends on the quality of the DNA, that must be free of contaminants and nucleases that impair the amplification process. The addition of thyocianate, cetyltrimethyl ammonium bromide or phenol extraction to the specimen (Boom et al. 1990, Masri et al. 1997), are some of the options available. In a recent study we reported the application of a plant proteinase during the isolation of DNA (Genelhu et al. 1998). We compare here, three DNA extractive procedures in association with the PCR technique. 


\section{MATERIALS AND METHODS}

Strains of Leptospira sp. - Serovars of Leptospira sp. used in this work are listed in the Table. The strains were supplied by the Centro Panamericano of Zoonoses, Panamerican Health Organization. L. interrogans serovar hardjo reference strain Hardjoprajitno (CTG) and $L$. borgpetersenii serovar mini reference strain Cantagalo (CTG) were isolated at the Laboratory of Zoonoses, Departament of Preventive Medicine, Veterinary School of UFMG and classified at the Royal Tropical Institute (KIT), Amsterdan. The organisms were cultured in liquid Ellinghausen medium, modified by Johnson and Harris (1967), during seven days under aerobic conditions in the dark at $27^{\circ} \mathrm{C}$.

DNA extraction - Exponentially growing organisms, were centrifuged at $13,000 \mathrm{x} \mathrm{g}$ for $30 \mathrm{~min}$ at $4{ }^{\circ} \mathrm{C}$, and the pellet was washed twice in phosphate-buffered saline (PBS). DNA was released from leptospires by either of the following methods: Method 1 - Incubation of bacteria in $200 \mu \mathrm{l}$ of buffer containing $50 \mathrm{mM}$ Tris ( $\mathrm{pH} 8.0$ ), $50 \mathrm{mM}$ EDTA, $100 \mu \mathrm{M} \mathrm{NaCl}, 1 \%$ SDS and $100 \mathrm{mg}$ of proteinase K (Sigma Chemicals, St. Louis, Missouri, USA) at $37^{\circ} \mathrm{C}$ for $2 \mathrm{~h}$. DNA was then subjected to phenol/chloroform/isoamyl alcohol (25:24:1) extraction and ethanol precipitation. The precipitate was collected by centrifugation, then dried and resuspended in $\mathrm{H}_{2} \mathrm{O}$. In order to remove the contaminating RNA, the solution was incubated with 20 $\mu \mathrm{g} / \mathrm{ml}$ of RNAase A (Amresco Inc., Solon, Ohio, USA) at $37^{\circ} \mathrm{C}$ for $2 \mathrm{~h}$ (Tamai et al. 1988); Method 2 - Incubation of leptospires in the buffer above described plus $50 \mu \mathrm{g}$ of a plant proteinase (E6870) (Genelhu et al. 1998) during $2 \mathrm{~h}$ at $37^{\circ} \mathrm{C}$, followed by extraction with phenol/chloroform/isoamyl alcohol (25:24:1) as described for Method 1; Method 3 - Boiling of $1 \mathrm{ml}$ of leptospire culture in $100 \mu \mathrm{l}$ of $0.1 \mathrm{mM}$ Tris $(\mathrm{pH} 7.0)$ for $10 \mathrm{~min}$ at $100^{\circ} \mathrm{C}$ (Corney et al. 1993).

The amount of DNA recovered after each procedure was determined by electrophoresis on a $1 \%$ agarose gel against $\lambda$ Hind III DNA. The gel was stained with ethidium bromide and the DNA concentration was determined by direct comparison with $\lambda$ DNA as standard.

$P C R$ - The PCR was undertaken with the primers previously described by Woodward and Redstone (1993): Lep 13, 5'CTCGGATCCTTAG ATATGCTGCAGAAGCTTG 3' and Lep 14, 5'AA AAGATCTTATGATTATGATCACAACCTG 3'. The reaction mix $(25 \mu \mathrm{l})$ contained $10 \mathrm{mM}$ Tris$\mathrm{HCl}$ (pH 9.0) buffer, $50 \mathrm{mM} \mathrm{KCl}, 100 \mu \mathrm{M}$ of each deoxynucleoside triphosphate, $800 \mathrm{nM}$ of each primer, $0.2 \mathrm{ng}$ of DNA, $2 \mathrm{mM} \mathrm{MgCl}{ }_{2}$ and $0.5 \mathrm{U}$ of Taq DNA polymerase (Gibco). The mix was covered with $15 \mu \mathrm{l}$ of mineral oil and PCR was performed in a Thermocycle MJ Research for 30 sequential cycles of $94^{\circ} \mathrm{C}$ for $90 \mathrm{~s}, 58^{\circ} \mathrm{C}$ for $90 \mathrm{~s}$ and $72^{\circ} \mathrm{C} 2 \mathrm{~min}$. The last elongation step was extended for $10 \mathrm{~min}$. With this protocol, the presence of a $849 \mathrm{bp}$ band indicates the successful amplification of the endoflagellin subunit gene (Woodward \& Redstone 1993) acting as a target sequence for the detection of the genus Leptospira.

Also, the DNA released with proteinase $\mathrm{K}$ and proteinase E6870 were used in association with RAPD-PCR protocols, to check for the ability to differentiate between serovars of Leptospira and to verify the quality of DNA obtained with E6870. We used a different set of primers, previously described by (Ramadass et al. 1997), B11; 5'CCGGAAGAAGGGGCGCCAT3' and B12; 5'CGATTTAGAAGGACTTGCACAC 3'. The RAPD-PCR reaction $(25 \mu \mathrm{l})$ was performed in 10 $\mathrm{mM}$ Tris- $\mathrm{HCl}$ (pH 9.0) buffer, containing $50 \mathrm{mM}$ $\mathrm{KCl}, 100 \mu \mathrm{M}$ each deoxynucleoside triphosphate, $4 \mathrm{nM}$ each primer, $50 \mathrm{ng}$ of DNA, $6 \mathrm{mM} \mathrm{MgCl} 2$ and $0.5 \mathrm{U}$ of Taq DNA Polimerase (Gibco). The reaction mixtures were covered with $15 \mu$ of mineral oil and PCR was performed in a Thermocycle MJ Research. The first two cycles consisted of denaturation at $95^{\circ} \mathrm{C}$ for $5 \mathrm{~min}$, annealing of primers at $40^{\circ} \mathrm{C}$ for $5 \mathrm{~min}$, and extension at $72^{\circ} \mathrm{C}$ for 5 $\min$. The subsequent 35 cycles consisted of denaturation at $95^{\circ} \mathrm{C}$ for $1 \mathrm{~min}$, annealing of primers at $58^{\circ} \mathrm{C}$ for $1 \mathrm{~min}$ and extension at $72^{\circ} \mathrm{C}$ for $3 \mathrm{~min}$.

TABLE

Leptospira sp. serovars used in the study

\begin{tabular}{llll}
\hline Genomic species & Serogroup & Serovar & Reference sample \\
\hline L. interrogans & Australis & bratislava & Jez bratislava \\
L. interrogans & Pomona & pomona & Pomona \\
L. interrogans & Sejroe & hardjo & Hardjoprajitno (OMS) \\
L. interrogans & Sejroe & hardjo & Hardjoprajitno (CTG) \\
L. borgpetersenii & Mini & mini & Cantagalo (CTG) \\
L. borgpetersenii & Mini & szwajizak & Szwajizak \\
L. borgpetersenii & Tarassovi & tarassovi & Perepelicin \\
\hline
\end{tabular}


The last elongation step was extended for $10 \mathrm{~min}$.

Following PCR the amplified DNA were deproteinized by phenol extraction and ethanol precipitation before further analysis.

Electrophoresis of PCR products - The amplified fragments were resolved on a 6\% PAGE gel for $45 \mathrm{~min}$ at $100 \mathrm{~V}$. Following electrophoresis the DNA was visualized by silver staining (Sanguinetti et al. 1994).

Serial dilution of Leptospira into urine - To determine the sensitivity of PCR with primers Lep13/Lep14, grown-up cultures of Leptospira were quantified using a Neubauer chamber, followed by 10 -fold serial dilution $\left(10^{9}\right.$ to $\left.10^{1}\right)$ of $L$. hardjo/Hardjoprajitno (CTG) into $1 \mathrm{ml}$ aliquots of urine.

\section{RESULTS AND DISCUSSION}

A comparison of three extracting procedures was carried out to determine which method yields more reliable results to be adopted in the future as standard procedure for diagnosis of Leptospira. PCR with primers Lep13/Lep14 was done after DNA was released by either, of the three methods outlined in the Methods section. Using proteinase $\mathrm{K}$ or E6870, it was observed a main band of 849 bp in each of the serovars assayed, in agreement with previous data (Woodward \& Redstone 1993) (Fig. 1A-C). In addition, a larger band (>2kb) was observed in some serovars (szwayizak, mini, pomona and hardjo/Hardoprajitno) regardless of the extracting procedure. Also, a $300 \mathrm{bp}$ was seen in serovars hardjo/Hardoprajitno CTG and OMS extracted with plant proteinase. With the exception of $L$. borgpetersenii serovar szwayizak the intensisty of the 849 bp specific for Leptospira obtained with plant proteinase is stronger than that obtained with proteinase $\mathrm{K}$. The densitometric analysis of the electrophoretogram (not shown) confirms this observation (Fig. 1A, B). The variation in the band intensities observed in some isolates, could be explained by differential amounts of DNA substrate added to the PCR reaction, although each DNA sample following extraction was dosed by agarose gel electrophoresis before PCR. Alternatively, these differences can be attributed to remaining contaminants within the DNA preparation that inhibit the PCR reaction (Longo et al. 1990). The improved DNA protection by E6870 can be explained by the presence of EDTA in the extracting buffer. The chelating agent, favors the proteolytic activity of E6870, while hampering the activity of proteinase $\mathrm{K}$. This notion was confirmed when the intactness of DNA obtained with plant proteinase was compared by agarose electrophoresis with the DNA extracted with proteinase $\mathrm{K}$, the former showing less sign of degradation than the latter.

On the other hand, no PCR products were obtained in some of the serovars samples [szwajizak, hardjo (OMS) and pomona] extracted by the boiling procedure (Fig. 1C). To verify whether the negative PCR resulting from this procedure is due to inefficient thermal lysis, the extracts subjected to this procedure were deproteinized by phenolchloroform and the nucleic acids concentrated by ethanol precipitation. The identity and relative size of the DNA recovered was evaluated on $1 \%$ agarose gel electrophoresis using 1 DNA Hind III as molecular weight marker (not shown). While the
$\mathbf{A}$

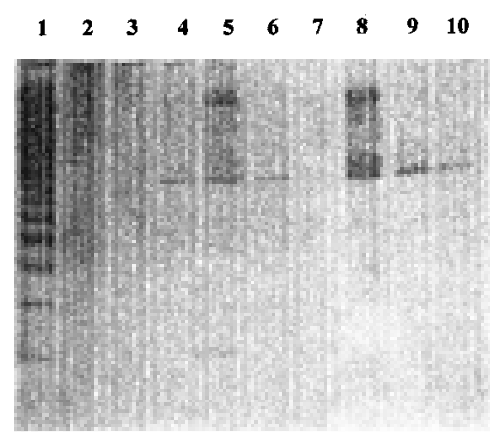

B

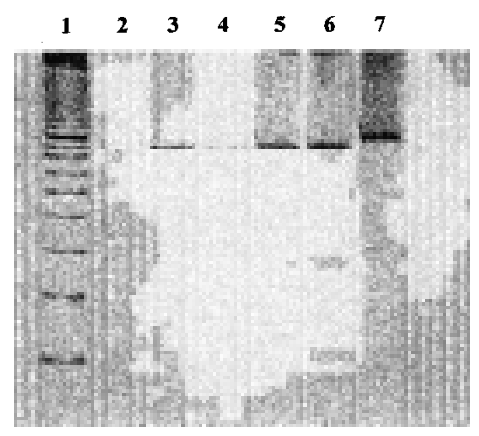

C

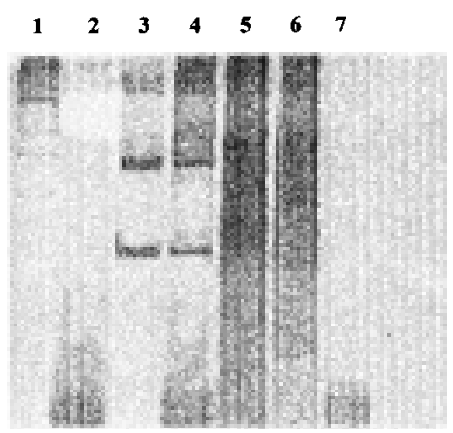

Fig. 1A-C: polyacrylamide gel electrophoresis of Leptospira DNA amplified by polymerase chain reaction (PCR) - Fifty percent (12.5 $\mu \mathrm{l})$ of the PCR reaction from various serovars amplified with primers Lep13/Lep14 as described in the Methods section were resolved by $6 \%$ non denaturing PAGE. A: serovars extracted with proteinase K; B: serovars extracted with E6870; C: serovars extracted by 10 min boiling of samples. A: lane 1, $100 \mathrm{bp}$; lane 2 and 3, negative control; lanes 4-10 are szwajizak, mini, hardjo (OMS), hardjo (CTG), pomona, bratislava, tarassovi; B: lane 1, $100 \mathrm{bp}$; lane 2, negative control; lane 3, positive control; lanes 47 are szwajizak, mini, hardjo (OMS), hardjo (CTG); C: lane 1, 100 bp; lane 2, negative control; lanes 3-7, mini, bratislava, hardjo/ Hardjoprajitno (OMS); szwajizak, pomona, respectively. 
PCR-positive samples obtained by the boiling procedure appear as faint smear, ranging in size from $2.3 \mathrm{~kb}-100 \mathrm{bp}$, a lack of DNA was evident in samples affording a negative PCR. We conclude from these results and from previous data, that while Leptospira serovars sejroe and hardjo, genotype Hardjobovis (Van Eys et al. 1989), serovars pomona, balcanica and hardjo (genotypes Hardjoprajitno and Hardjobovis) (Corney et al. 1993) release their DNA, other serovars are inefficiently disrupted using the boiling method. These experiments were repeated several times with different culture batches, yet the results showed the same profile described earlier; i.e. the PCR positive serovars continued to yield positive results, while refractory serovars showed no PCR amplification. These results suggest that differences in the cell wall structure may account for the variation in sensitivity to the boiling procedure. A similar situation has been previously reported in Mohran et al. (1998) with Campylobacter isolates.

In addition, the proteinase $\mathrm{K}$ and the plant proteinase procedures were used in combination with a different protocol, the RAPD-PCR of DNA from Leptospira. Using proteinase $\mathrm{K}$ in five strains or the plant proteinase in four strains of Leptospira with primers B11/B12, resulted in amplification of several bands ranging in size between 100 to 1000 bp (Fig. 2A, B). Again, the profiles obtained with serovar hardjo/ Hardjoprajitno match the results previously reported. Also, the profiles obtained with E6870 (Fig. 3), showed less background than those obtained with proteinase K, (Fig. 2A, B), suggesting that DNA extracted with plant proteinase was more intact. Two of the strains in these experiments have not been previously characterized by the RAPD-PCR technique [L. borgpetersenii serovar mini and $L$. interrogans serovar hardjo/Hardjoprajitno (CTG)].

Finally, the sensitivity of the PCR protocol involving DNA extraction with plant proteinases was evaluated by serially diluting $\left(10^{10}\right.$ to $\left.10^{1}\right)$ live leptospira into urine from cattle, followed by DNA extraction and PCR as described in the Methods section. The results of these experiments shown in Fig. 3 reveal that up to 100 Leptospira could be
A

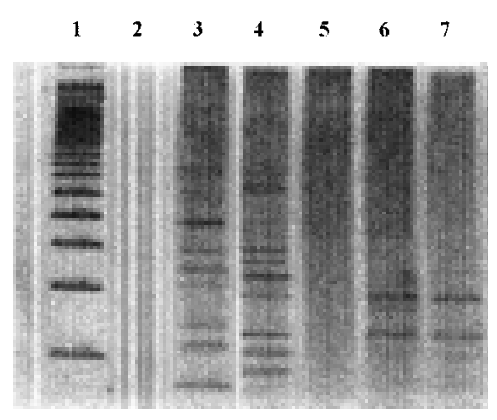

B

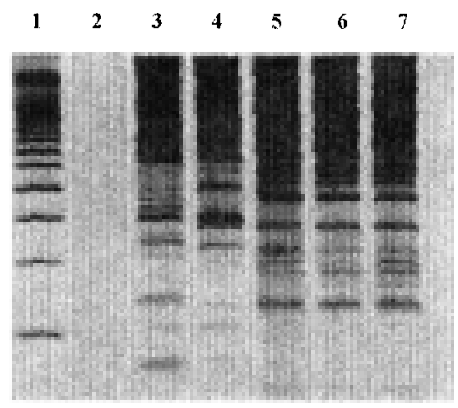

Fig. 2A-B: polyacrylamide gel electrophoresis of Leptospira DNA amplified by RAPD-polymerase chain reaction (PCR) - Fifty percent $(12.5 \mu \mathrm{l})$ of the PCR reaction from various serovars amplified with primers B11/B12 as described in the Methods section were resolved by $6 \%$ non denaturing PAGE. A: serovar extraction with proteinase K; B: serovar extraction with E6870; A: lane 1, 100 bp; lane 2, negative control; lanes 3-7 are szwajizak, mini, hardjo (OMS), hardjo (CTG), bratislava.

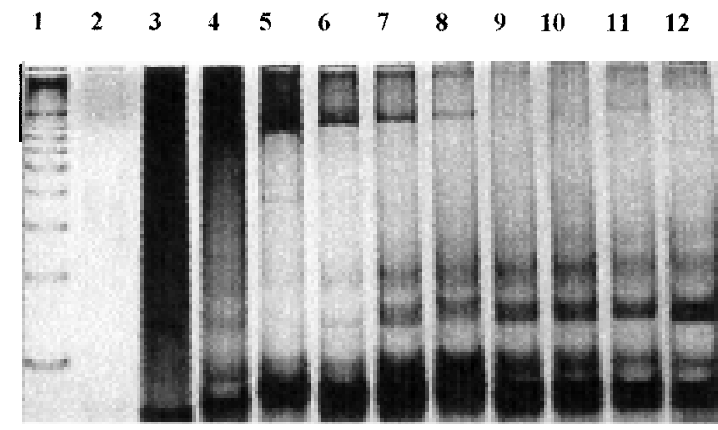

Fig. 3: polyacrylamide gel electrophoresis of serially diluted Leptospira in cattle urine followed by polymerase chain reaction (PCR) amplification - Fifty percent $(12.5 \mu \mathrm{l})$ of the PCR reaction from serovar hardjo/Hardjoprajitno (CTG) amplified with primers Lep13/Lep14 as described in the Methods section were resolved by $6 \%$ non denaturing PAGE. lane 1, $100 \mathrm{bp}$; lane 2, negative control; lanes $3-12$ are $10^{10}, 10^{9}, 10^{8}, 10^{7}, 10^{6}, 10^{5}, 10^{4}, 10^{3}, 10^{2}, 10^{1}$ cells $/ \mathrm{ml}$, respectively. 
detected by using this procedure. This result supports the potential of the PCR procedure when applied to the diagnosis of Leptospira, as infected cattle secret about $10^{5}$ microorganisms $/ \mathrm{ml}$ urine during the infected state.

\section{REFERENCES}

Bal AE, Gravekamp C, Hartskeerl RA, De Meza Brewster J, Korver H, Terpstra, WJ 1994. Detection of leptospires in urine by PCR for early diagnosis of leptospirosis. J Clin Microbiol 32: 1894-1898.

Boom R, Sol CJA, Salimans MMM, Jansen CL, Wertheim-van Dillen PME, Noordaa J van der 1990. Rapid and simple method for purification of nucleic acids. J Clin Microbiol 28: 495-503.

Brown PD, Gravekamp C, Carrington DG, Van de Kemp H, Hartskeerl RA, Edwards CN, Everard COR, Terpstra WJ, Levett PN 1995. Evaluation of the polymerase chain reaction for early diagnosis of leptospirosis. J Med Microbiol 43: 110-114.

Corney BG, Colley J, Djordjevic SP, Whittington R, Graham GC 1993. Rapid identification of some Leptospira isolates from cattle by random amplified polymorphic DNA fingerprinting. J Clin Microbiol 31: 2927-2932.

Ellis WA 1986. Leptospirosis. J Small Anim Pract 27: 683-692.

Ellis WA 1994. Leptospirosis as a cause of reproductive failure. Vet Clin North Am Food Anim Pract 10: 463478.

Genelhu MS, Zanini, MS, Veloso IF, Carneiro AMD, Lopes MTP, Salas CE 1998. Use of cysteine poteinase from Carica candamarcensis as a protective agent during DNA extraction. Braz J Med Biol Res 31: 1129-1132.

Gerritsen MJ, Olyhoek T, Smits MA, Bokhout BA 1991. Sample preparation method for Polymerase Chain Reaction - based semiquantitative detection of Leptospira interrogans serovar Hardjo subtype Hardjobovis in bovine urine. J Clin Microbiol 29: 2805-2808.

Gravekamp C, Van de Kemp H, Franzen M, Carrington D, Schoone GJ, Van Eys GJJM, Everard COR, Hartskeerl RA, Terpstra WJ 1993. Detection of seven species of pathogenic leptospires by PCR using two sets of primers. J Gen Microbiol 139: 1691-1700.

Johnson RC, Faine S 1994. FAMILY II. Leptospiraceae. In NE Krieg \& JG Holt (eds), Bergey's Manual of Systematic Bacteriology, Williams \&Wilkins, Balti- more, p. 62-67.

Johnson RC, Harris VG 1967. Differentiation of pathogenic and saprophytic leptospires. 1. Growth at low temperatures. J Bacteriol 94: 27-31.

Longo MC, Berninger M, Hartley J 1990. Use of uracil DNA glycosylase to control carry over contamination in Polymerase Chain Reaction. Gene 93: 125128.

Masri AS, Nguyen PT, Pamela Gale S, Howard CJ, Chan Jung S A 1997. Polymerase Chain Reaction assay for the detection of Leptospira spp. in bovine semen. Can J Vet Res 61: 15-20.

Merien F, Amouriaux P, Perolat P, Baranton G, Saint Girons I 1992. Polymerase Chain Reaction for detection of Leptospira spp. in clinical samples. J Clin Microbiol 30: 2219-2224.

Mohran ZS, Arthur RR, Oyofo BF, Peruski LF, Wasfy MO, Ismail TF, Murphy JR 1998. Differentiation of Campylobacter isolates on the basis of sensitivity to boiling in water as measured by PCR-detectable DNA. Appl and Environ Microbiol 64: 363-365.

Ramadass P, Meerarani S, Venkatesha MD, Senthilkumar A, Nachimuthu K 1997. Characterization of leptospiral serovars by randomly amplified polymorphic DNA fingerprinting. Int $J$ Syst Bacteriol 42: 215219.

Romero EC, Billerbeck AEC, Lando VS, Camargo ED, Souza CC, Yasuda PH 1998. Detection of Leptospira DNA in patients with aseptic meningitis by PCR. $J$ Clin Microbiol 36: 1453-1455.

Sanguinetti CJ, Dias Neto E, Simpson AJG 1994. Rapid silver staining and recovery of PCR products separated on polyacrylamide gels. Biotechniques 17:915919.

Tamai T, Sada E, Kobayashi Y 1988. Restriction endonuclease DNA analysis of Leptospira interrogans serovars Icterohaemorrhagiae and Copenhageni. Microbiol Immunol 32: 887-894.

Van Eys GJJM, Gravekamp C, Gerritsen MJ, Quint W, Cornelissen TEM, Ter Schegget T, Terpstra WJ 1989. Detection of leptospires in urine by Polymerase Chain Reaction. J Clin Microbiol 27: 2258-2262.

Woodward MJ, Redstone JS 1993. Differentiation of leptospira serovars by polymerase chain reaction and restriction fragment length polymorphism. Vet Rec 132: 325-326.

Zanini MS, Moreira EC, Lopes MTP, Mota P, Salas CE 1998. Detection of Mycobasterium bovis in milk by polymerase chain reaction. $J$ Vet Med B 45: 473479. 